\title{
The Effect of Perceived Service Quality on Customer Loyalty in Internet Service Providers in Jordan
}

\author{
Bader Yousef Obeidat \\ Assisstant Professor of Strategic Management, Department of Business Management \\ Faculty of Business, The University of Jordan, Amman, Jordan \\ E-mail: b.obeidat@ju.edu.jo \\ Rateb J. Sweis \\ Associated Professor, Department of Business Management, Faculty of Business \\ The University of Jordan, Amman, Jordan \\ E-mail: r.sweis@ju.edu.jo \\ Diana Shawqi Zyod \\ Faculty of Business, The University of Jordan, Amman, Jordan \\ E-mail: dianasabaneh@yahoo.com \\ Ra'ed (Moh'd Taisir) Masa'deh \\ Assistant Professor of Management Information Systems, Faculty of Business \\ The University of Jordan, Amman, Jordan \\ E-mail: r.masadeh@ju.edu.jo \\ Muhammad Alshurideh \\ Assisstant Professor of Marketing, Marketing Department, Faculty of Business \\ The University of Jordan, Amman, Jordan \\ E-mail:m.alshurideh@ju.edu.jo
}

Received: July 22, 2012 Accepted: September 6, 2012 Published: October 1, 2012

doi:10.5296/jmr.v4i4.2130

URL: http://dx.doi.org/10.5296/jmr.v4i4.2130

\begin{abstract}
This study investigates the impact of perceived service quality on customer loyalty in the Internet Service Provider industry in Jordan. The framework of this study was developed based
\end{abstract}




\section{Macrothink}

on previous research. Perceived service quality was dealt with as an independent variable which was measured using five dimensions based on Parasuraman et al. initial study carried out in 1988. Customer loyalty was treated as a dependent variable which was measured by 13 items previously proposed by Zeithaml, et al. (1996). Taking into consideration the fact that Umniah Company was the first to acquire Wimax, a convenient sample was adopted inside the company in which 420 survey questionnaires were distributed to its customers.

Multiple regression analysis was used to analyze the data of this study. The results show that perceived service quality in terms of tangibles, reliability, responsiveness, assurance, and empathy significantly affect customer loyalty. More specifically, it is found that the empathy dimension is the strongest predictor of customer loyalty.

Keywords: Perceived Service Quality, Customer Loyalty, Internet Service Providers, Jordan 


\section{Introduction}

Over the past years, organizations and individuals in various places in the world have felt the benefits of Internet which has evolved prominently (Clinton, 2010). Due to the many services it offers, such as the ease of creation of service, single standard, and the ability to cross national boundaries, the popularity of internet is increasing at a remarkable rate. However, as stated by Chiou (2004), in order to have access to the internet and enjoy its features, any consumer needs an Internet Service Provider (ISP). ISP is an organization that supplies its customers with direct connections to the Internet and thus provides access to a full set of internet services to anyone possessing a computer and a modem (Geer, 2003). According to Chiou (2004), sooner or later, every consumer who wants to connect to the internet will have to choose an ISP. Consequently, in Jordan for instance, as in any other place in the world, the increase in the number of people using the internet leads also to an increase in the number of ISP in the market (Arab Advisors Group, 2009).Nevertheless, now it is insufficient to just provide a service to customers, because what was considered good enough in the past is not enough now (Coyles and Gokey, 2005). If a customer feels that the service delivered to him/her does not meet or exceed his/her expectations, he/she will easily switch to another company. So, instead of focusing only on acquiring new customers, making loyal customers can help an organization survive in this competition (Grewal et al., 2009). Indeed, any service organization that wants to survive and gain a competitive advantage needs to care about its customers. For this reason, it is important for a service organization to understand its customers, to be aware of their needs and expectations, and of course to know how they perceive the quality of the service provided to them.

Indeed, the concepts of perceived service quality and customer loyalty have been investigated separately with the purpose of understanding each term alone (e.g. Parasuraman, et al., 1985; Pan and Xie, 2008). However, despite the fact that gaining loyal customers and providing high quality services have been considered important issues for the continuous success of any company (Vanniarajan and Gurunathan, 2009), there is a lack of studies focusing on the interaction of these two concepts, especially in the ISP industry. Moreover, in order to cultivate loyal customers, it is important for any company to know what to focus on and improve to reach loyalty. Besides, firms are continually looking for new ways to differentiate their offerings since achieving and preserving a strong competitive position in the marketplace is becoming ever more difficult due to the increased competition, more demanding customers, and propagation of look-alike, similarly priced brands (Rahman, 2006). In addition, Wicks and Roethlein (2009) stated that higher levels of loyalty and greater profitability can be enjoyed by organizations if they constantly satisfy their customers. Hence, one method that companies may adopt is to provide better quality than their competitors since according to Lorenzo et al. (2010) customers remain faithful to companies providing quality service systematically. However, to provide quality service, it is important to determine how service quality is perceived by customers and what do they mean by quality because the problem that most companies confront knows how to offer quality service that will lead to customer loyalty (Lorenzo, et al., 2010). Thus, studying perceived service quality and examining its effect on customer loyalty may help organizations in surviving strong competition. Furthermore, in the ISP market, it is difficult for a company to differentiate itself from competitors, and it is 
becoming harder (Geer, 2003). Customer demands are becoming more and more sophisticated and one of the biggest issues for customers of ISPs is the quality and consistency of the service provided to them (Geer, 2003). This is due to the fact that several organizations allocate considerable resources to measure and monitor quality in order to gain customer loyalty. Accordingly, the importance of this study stems from the fact that it provides useful and valuable information to any ISP in Jordan which is interested in making success from loyal customers. It also increases the understanding of ISPs about the effect of perceived service quality on each element of customer loyalty. All in all, since there is a scarcity of studies examining the effect of perceived service quality on customer loyalty in the Jordanian ISP industry, this research aims to do so.

\section{Literature Review and Research Hypotheses}

The ISP market first began in February 1996 when Global One Communication (Jordan) Ltd. (later known as Wanadoo) was established in Jordan. In the early years, the growth rate of internet subscriptions was extremely high reaching $200 \%$ in 1997 . Furthermore, according to Internet World Stats, Internet usage in Jordan grew by 259\% between 2000 and 2005 (Ministry of ICT, 2011). Therefore, the ISP market in Jordan is highly advanced and moving fast. Currently, there are 10 operational ISPs sharing the market and competing between them, with a narrow customer base of 291,067 subscribers in which it is expected to reach 450,000 by the end of 2012 (Ministry of Information and Communication Technology, 2011).

Also, there are a variety of ways to access the internet here in Jordan. At the beginning, ADSL lines and Dial up were the most popular means of access. However, after a while, the trend has been moving from Dial Up towards ADSL and most ISPs have been increasing focus on broadband services and cutting prices for ADSL to encourage subscribers (Capital Investment, 2006). Nowadays, after the launch of wireless internet (Wimax) by Umniah in 2007 (Jordan Business, 2007), the most common Internet Broadband services that ISPs provided to their customers are ADSL, Wimax, and Dial up which, although it is still used, is decreasing rapidly (Umniah, 2011). However, not all ISPs have the ability to provide these three services to their customers; some of them provides only one service (Jordan Business, 2007). According to the market share, Orange, Umniah, and Zain are the largest ISPs working in Jordan (Ministry of ICT, 2011). Furthermore, these three ISPs are the largest telecommunication companies and the best known brands in Jordan. However, Orange provides only ADSL and Dial up services while Umniah and Zain provide ADSL, Dial up, and Wimax services. Furthermore as cited above, Umniah was the first ISP to acquire Wimax license in Jordan (Umniah, 2011).

Indeed, the quality of a service is sometimes more important for customers than the cost of acquiring that service (Ranaweera and Neely, 2003). Therefore, to satisfy customers, a service organization needs to understand how customers evaluate the quality of the service they receive and the basis on which they become loyal to that organization (Kandampully, 1998). For this reason, organizations have to focus on providing customers with the highest possible level of quality. Based on previous experiences, communication, image, word-of-mouth and their own needs, customers create in their minds expectations of the service they are going to purchase (Holmund and Kock, 1996). In addition to that, the superiority of the service offered by an organization depends on customer perception of service quality and not on the organization's perception of the service offered (Lobo, et al., 2007). In literature, the result of 
the comparison that customers made between these expectations and the perception of the method by which the service has been delivered is known as the perceived service quality (Lehtinen and Lehtner, 1982; Lewis and Booms, 1983; Parasuraman et al., 1983, 1985, 1991, 1994; Gronroos, 1984; Zeithaml, 1987; Xu, et al., 2006).

The concept of service quality developed from the quality literature in manufacturing (Shonk and Chelladurai, 2008). Service quality has been connoted with many business disciplines. Shonk and Chelladurai (2008) stated that service quality has been associated with customer loyalty (Kandampully, 1998; Parasuraman, et al., 1990), customer satisfaction (Ko and Pastore, 2004), value (Laroche, et al., 2004), and repurchase intention (Fornell, 1992). Even if it is not easy to define the term service quality, marketing theorists generally agree that customer perception can be considered as a crucial of its conceptualization (González, et al., 2007). Thus, the main operationalization of service quality is perceived service quality (Xu, et al., 2006).

Zeithaml (1987) defined perceived quality as customer's judgment about a product's overall excellence or superiority. In their study, Yu, et al. (2005) stated that perceived quality constitute of customization and reliability. Others viewed it as the degree to which customer's perceptions and expectations of a particular service differ from each other and direction (Xu et al., 2006; Shonk and Chelladurai, 2008). In this study, following the definition provided by Xu, et al., (2006), perceived service quality is defined as the comparison that customers made between the expectations and the perception of the method by which the service has been delivered.

Quality measurement in service firms differs from quality measurement in manufacturing firms. When measuring service quality, the primary focus must be on external quality which is the service quality perceived by customers (Holmund and Kock, 1996). In his model of perceived quality, Chao (2008) argued that service quality consists of two attributes, technical attribute which refers to what is delivered to customers and the functional one which refers to how the service is delivered to the customer. In their study, Yu et al. (2005) used overall quality, customization, and reliability as indicators to measure perceived quality. However, Koivisto and Urbaczewski (2004) argued that the perceived quality of service can be measured by two methods, opinion polls and customer satisfaction surveys. In another study, Cronin and Taylor (1994) mentioned two tools for measuring service quality, the SERVPERF scale and the SERVQUAL scale. SERVPERF, which was developed by Cronin and Taylor based on the assumption that service quality is a form of customer attitude, measures service quality based on performance (Chadha and Kapoor, 2009). According to Xu, et al. (2006), SERVQUAL, the 22-item scale developed by Parasuraman et al. (1988), is considered one of the most widely used instruments in the measurement of service quality and is based on fives dimensions:

1. Tangibles: physical facilities, equipment, and appearance of personnel.

2. Reliability: ability to perform the promised service dependably and accurately.

3. Responsiveness: willingness to help customers and provide prompt service.

4. Assurance: knowledge and courtesy of employees and their ability to inspire trust and confidence.

5. Empathy: caring, individualized attention that the firm provides its customers. 
In many studies that examined and required the measurement of perceived service quality, researchers talked positively, or encouraged, and used the SERVQUAL instrument. Chadha and Kapoor (2009) stated that various measurement models have been developed for measuring service quality and the most reliable and widely used of them in researches is the SERVQUAL scale. In addition, Lobo, et al. (2007) stated that the SERVQUAL model which was developed by Parasuraman et al. $(1985,1988)$ to measure customers' perception of quality, conceptualized the most commonly used set of service quality determinants. Seth et al. (2008) measured customer perceived service quality for cellular mobile telephony in the Indian market using the five dimensions of SERVQUAL and two additional dimensions. In their study, Chadha and Kapoor (2009) used SERVQUAL to examine service quality in mobile telecommunication outlet in South Africa and argued that the SERVQUAL instrument was reliable. In addition to that, when investigating the antecedents of customer loyalty, Yieh, et al. (2007), used the SERVQUAL with some modifications to measure perceived service quality.

Defining loyalty has been challenging for many researchers, mostly because of the imprecise and varying conceptualizations of the construct (Martin, et al., 2009). Nevertheless, literature offers an abundance of definitions of loyalty (Khan, 2009). For example, Oliver (1999, p.34) defined it as "a deeply held commitment to re-buy or re-patronize a preferred product/service consistently in the future, thereby causing repetitive same-brand or same brand-set purchasing, despite situational influences and marketing efforts having the potential to cause switching behavior". However, Yieh, et al. (2007) regarded customer loyalty as simply the repetition of a purchasing behavior towards a company's product. In this study, following the definition provided by Bloemer, et al. (1999), customer loyalty is defined as the service that first comes to the mind of the customer when making a purchase decision, and is the first choice of the customer among alternatives or price tolerance.

Despite the fact that different definitions of loyalty can be found in different research and different contexts, there seem to be two basic approaches for the concept of customer loyalty (Jacoby and Kyner, 1973). These are described as the behavioral approach and the attitudinal approach. The behavioral approach defines and measures customer loyalty as a behavior (Martin, et al., 2009). In most of the early studies the behavioral dimension of loyalty was emphasized, such as the repeat purchase of a particular product or service (Yim, et al., 2008). This approach assumes that the preference structure or first choice of the customer is reflected in and can be measured by the customer's behavior (Khan, 2009). Thus the operational measures of this dimension of loyalty are purchasing frequency, proportion of purchase. According to Liang and Wang (2004), customer behavioral loyalty represents the possibility that the customer will repeat purchase and voluntarily become a member of the company. Furthermore, Heskett, et al. (1994) stated that the repetition of purchase or the intentions to repeat purchase could be used to measure the loyalty of brand or service. The attitudinal approach defines and measures customer loyalty as an attitude (Copeland, 1923). Some researchers, like Monroe and Guiltinan (1975) which is among the most keen advocates of this approach, view loyalty from an attitudinal perspective and speak in favor of it (Khan, 2009). Accordingly, Shankar, and his colleagues (2003) defined customer loyalty as an attitude that indicates the long-term commitment of the customer to the organization. In their definition of attitudinal loyalty, Fitzgibbon and White (2005) stated it was the tendency of a customer 
towards a brand due to a psychological process. Besides, the concept of attitudinal loyalty follows the cognitive school of thought where cognitive researchers focus on the role of processes in defining loyalty (Bennett and Rundle-Thiele, 2002). Operational measures of this form of loyalty are preference, buying intention, supplier prioritization and recommendation willingness (Khan, 2009).

Conceptualizations have changed over years to become more meaningful, including both attitudinal (psychological) and behavioral dimensions of loyalty (Chao, 2008). Many researchers (Jacoby and Kyner, 1973; Dick and Basu, 1994; Berne, et al., 2001) have realized that there was a need to add an attitudinal component to the behavioral component (Bodet, 2008). Thus a comprehensive measure of customer loyalty cannot neglect the measurement of either attitude or behavior of customers (Harris and Goode, 2004). In addition to that, most of the research (e.g. Rowley, 2004; Xu, et al., 2006) when conceptualizing customer loyalty stated it was an interaction of attitudes and behaviors. According to the attitudinal approach, it is not sufficient to just describe the actual behavior of the customer in order to give a real explanatory value to the concept of loyalty (Khan, 2009). Moreover, repeat purchases do not necessarily mean that a long-term relationship has been established between the customer and the organization (Webster, 1992). However, a customer may have a relative attitude toward a brand without having the intention of purchasing it (Martin, et al., 2009).

In his study, Rundle-Thiele (2005) analyzed five dimensions of loyalty which are situational loyalty, resistance to competing offers (price sensitivity), attitudinal loyalty, complaining behavior, and propensity to be loyal. Nevertheless, according to Lobo, et al. (2007), the five dimension that constitute loyalty are recommending the organization to someone asking for an advice, encouraging people to do business with the organization, saying positive things about the organization to others, engaging the service of the organization in the next years, and finally considering the organization as the first option for future purchase decisions. In addition, Ibrahim and Najjar (2008) also stated that loyalty is a multi-dimensional construct which consists of five dimensions, which are the tendency to switch, loyalty to the organization, the willingness to pay more, the internal response to problem, and the external response to problem. By adding to and extending the earlier work done in conceptualizing loyalty, Oliver (1997) developed a detailed framework that defines loyalty in terms of four phases (Harris and Goode, 2004, p141). First, cognitive loyalty refers to the existence of beliefs that (typically) a brand is preferable to others. Second, affective loyalty reflects a favorable attitude or liking based on satisfied usage. Third, conative loyalty constitutes the development of behavioral intentions characterized by a deeper level of commitment (e.g., Zeithaml, Berry, and Parasuraman, 1996; Hennig-Thurau, et al., 2002; Janda, et al., 2002). Finally, action loyalty relates to the conversion of intentions to action, accompanied by a willingness to overcome impediments to such action.

Through the past few decades perceived service quality has received a lot of attention from researchers and practitioners because of its significant effect on business performance, customer satisfaction, profitability, and customer loyalty (Santouridis and Trivellas, 2010). In addition to that, Parasuraman, et al. (1994) confirmed that superior service quality not only helps the organization to attract the support of new customers, but also encourage repeat purchases by existing customers as well. Therefore, perceived service quality can be 
considered as the most effective business effort available to organizations which want to gain customer loyalty (Parasuraman, et al., 1988). Koivisto and Urbaczewski (2004) stated that when the service provided is Internet, it is not sufficient to measure network performance to determine the quality of the service perceived by the user because they are different construct and are measured differently. Based on above discussion, this study has led to the following hypotheses:

$\mathbf{H}_{\mathbf{1}}$ : There is a statistically significant impact of perceived service quality in term of tangibles on customer loyalty.

$\mathbf{H}_{2}$ : There is a statistically significant impact of perceived service quality in term of reliability on customer loyalty.

$\mathbf{H}_{3}$ : There is a statistically significant impact of perceived service quality in term of responsiveness on customer loyalty.

$\mathbf{H}_{4}$ : There is a statistically significant impact of perceived service quality in term of assurance on customer loyalty.

$\mathbf{H}_{5}$ : There is a statistically significant impact of perceived service quality in term of empathy on customer loyalty.

\section{Research Methodology and Data Collection}

\subsection{Population, Sample, and Data Collection}

The population of this study consists of ISPs internet subscribers (Wimax, ADSL, and Dial up) of Umniah Company in Jordan (i.e. 25700). Indeed, Umniah Company was chosen because of the readiness access as it was merely accepted to cooperate with us, besides it was the first ISP to acquire Wimax license in Jordan. To develop an appropriate sample from the population selected for this study, convenience sampling was used due to the fact that the population is very large and the needed data were not readily available. In addition, it was difficult to have access to information (e.g. emails or mobile numbers) that could help in contacting or reaching customers because of privacy and security issues. Moreover, the sample size for a population consisting of 291067 subscribers (according to Umniah Company statistics in 2011), as mentioned in Sekaran (2003), must be 384. In order to arrive to this size, Umniah accepted to administer the questionnaires designed for this study to its internet subscribers as they came to pay their bills at its different sales shops. There are 35 Umniah sales shops dispersed in various cities in Jordan (according to Umniah Company statistics in 2011), and the questionnaires were distributed by Umniah's employees to customers visiting these sales shops. The total number of questionnaires returned was 443 from which 420 were found to be valid.

\subsection{Measures}

As this research is deductive and quantitative in nature, one of the important characteristic of deduction is the need to operationalize the variables of the study in a way that facilitate the measurement of facts quantitatively (Saunders et al, 2007). The items selected to measure the concepts of perceived service quality and customer loyalty were primarily derived and adapted from existing literature and prior studies. However, some modifications were made to each scale to fit the context of this study. Perceived service quality was measured using five dimensions (tangibles, reliability, responsiveness, assurance, and empathy) of SERVQUAL (Parasuraman et al., 1988), which is an instrument consisting of 22 itemsi used for assessing 
customer perceptions of service quality in service organizations. Adopted from a study (Eze, et al., 2008) done in ISPs where the same instrument (SERVQUAL) was successfully used and was found to be reliable (Cronbach's alpha was more than 0.70), for all study items. The perceived service quality was measured using a five-point rating scale rating from one: 'strongly disagree' to five: 'strongly agree'.The dependent variable, cus.tomer loyalty, was assessed based on the proposals of Zeithaml, et al. (1996). The 13 items for customer loyalty scale for the study was adapted from the scale developed and validated by Sanchez-Franco et al. (2009) for ISPs and which was found to be reliable (Cronbach's alpha was more than 0.70). All items were measured using a five-point rating scale rating from one: 'strongly disagree' to five: 'strongly agree'.

\section{Data Analysis and Results}

In order to examine the research hypotheses, the data collected through the questionnaire distributed to the customers were analyzed using Statistical Package for Social Sciences (SPSS) version 16.

\subsection{Profile of the Respondents}

The respondents for this study were asked to give information about their gender, age, educational level, and family status. From the results appeared in the appendix table 1, it can be seen that the number of male are more than female which may imply than men have more time to use internet or even need it more for work, and women even if they need it use it less. Also, there is almost no difference between married and single respondents. Thus, this suggests that people who are married are need internet services and have the time to using them in the same way as people who are single.

\subsection{Reliability Testing (Cronbach Alpha)}

In this study, scale reliability was assessed using Cronbach's alpha coefficient. The appendix table 2 presents the Cronbach's alpha coefficients for the different dimension and variables of the questionnaire. Indeed, it can be seen that the results range from 0.713 to 0.856 . Therefore, all values exceed the recommended threshold 0.70 , indicating good internal consistency among the items within each dimension, each variable, and the entire scale.

\subsection{Hypothesis Testing}

Before testing the hypotheses, multicollinearity diagnosis was done using Variance Inflation Factor (VIF) and tolerance value. As shown in the appendix table 3, it can be seen that VIF rangebetween 1.936 and 2.985 values which are well-below five. On the other hand, the tolerance values range between 0.335 and 0.517 which are above 0.2 . These factors indicate that there is no evidence of multicollinearity problem in the regression model. In addition to the VIF and tolerance values, Pearson Correlation Matrix was computed the imdependent variable dimensions to check correlation between them as shown in the appendix table 4 . According to Sekaran (2003), a value of 0.75 and above suggests high correlation between the variables. The results in the above table, are all below 0.75 and thus do not suggest high correlation between the variables. Therefore, these findings also show that there is no evidence of multicollinearity problem. 
In order to test the study hypotheses, multiple regression was used. Customer loyalty was entered as the dependent variable and perceived service quality (tangibles, reliability, responsiveness, assurance, and empathy) as the independent variables.

Table I. Multiple Regression For The Hypotheses

\begin{tabular}{|l|c|c|c|c|c|c|}
\hline & $\begin{array}{r}\text { Adjusted } \\
\text { R Square }\end{array}$ & $\mathrm{F}$ & Sig. & Beta & $\mathrm{T}$ & Sig. \\
\hline Tangibles & & & & .173 & 3.507 & .001 \\
Reliability & & & & .172 & 2.885 & .004 \\
Responsiveness & .501 & 85.163 & .000 & .127 & 2.292 & .022 \\
Assurance & & & & .116 & 2.025 & .044 \\
Empathy & & & & .264 & 5.497 & .000 \\
\hline
\end{tabular}

The above table shows that $F(5,414)=85.163$ and $p$-value $=0.000$. Since the $p$-value is smaller than the level of significance (0.05), all the hypotheses are accepted at $p<0.05$ significance level. Hence, there is a statically significant impact of perceived service quality (tangibles, reliability, responsiveness, assurance, and empathy) on customer loyalty. The positive effect of perceived service quality on customer loyalty had been supported in various studies (e.g. Zeithaml, et al., 1996; Bloemer, et al., 1999; Clottey, et al., 2008). Furthermore, perceived service quality had been considered by many researchers as a determinant or antecedent of customer loyalty (Boulding, et al., 1993; Cronin and Taylor, 1994; Dick and Basu, 1994). Therefore, the findings are consistent with the results found in numerous previous studies.

Moreover, as shown in table I, the adjusted R Square's value of $(0.501)$ indicates the proportion of the variance in the criterion variable which is accounted for by the model and shows that about $50 \%$ of the variance in customer loyalty has been significantly explained by perceived service quality. The fact that perceived service quality explained half of the variance in customer loyalty, may be due to the absence of other factor explaining the other half. According to Pan and Xie (2008), trust, perceived value, and perceived fairness have strong effect on customer loyalty. Therefore, besides perceived service quality; there may be different factors influencing customer loyalty (Ribbink, et al., 2004; Lin and Wang, 2006; Ibanez, et al., 2006; White, 2006; Cheng, et al., 2008; Chen, at al., 2009; Afsar, et al., 2010). Furthermore, when testing this hypothesis in the transport service sector and banking sector, Lei and Mac (2005), and Ravichandran, et al. (2010) found a significant impact of the predictor on the criterion with an explained variance of $37.5 \%$ and $44.3 \%$ respectively. Thus, compared to these researches, it might be stated that perceived service quality explained to a relatively good extent the variance in customer loyalty in the ISP industry.

The $t$ and sig. (which is known as p-value) values, as shown in table $\mathrm{I}$, give a rough indication of the impact of each predictor variable (Kumar, et al, 2010). A big absolute t value and small $p$ value suggests that a predictor variable is having a large impact on the criterion variable. The 
results show that all perceived service quality dimensions have a significant impact on customer loyalty. Also, the standardized beta coefficient is a measure of the contribution of each predictor or how strongly each predictor variable influences the criterion variable (Kumar, et al, 2010). A large value indicates that a unit change in this predictor variable has a large effect on the criterion variable. The strongest predictor for customer loyalty is empathy, achieving a $\beta$ of 0.264 , followed by tangibles $(\beta=0.173)$, reliability $(\beta=0.172)$, and responsiveness $(\beta=0.127)$. The last factor influencing customers loyalty towards their ISP is assurance $(\beta=0.116)$. Parasuraman, et al., (1988), stated that regardless of the service setting, reliability is considered to be the most important and tangibles the least important service quality dimensions with respect to customer loyalty. On the other hand, Lei and Mac (2005) found that reliability had no significant impact on customer loyalty in the Chinese transport service sector while Ravichandran, et al. (2010) found that tangibles was the strongest predictor in the banking industry. Therefore, the difference in the predictor importance between the different studies may be due to cultural differences or industry characteristics differences.

The findings revealed that empathy is the strongest or most important predictor of customer loyalty in ISPs in Jordan. This may be due to the fact that each person is by nature attracted to source of caring, compassion, and individualize attention and it seems that ISPs' customers in Jordan give great importance to empathy. Thus, this indicate that factors such as individual attention and personal attention, understanding interests and needs, and convenient operating hours are most essential in bringing about customer loyalty. According to Bloemer, et al. (1999), customer loyalty is primarily affected in a positive manner by responsiveness and empathy for entertainment services, by assurance and empathy for fast food service industry, by reliability for supermarkets, and by empathy for health care service. Indeed, it seems that empathy plays an important role in determining customer loyalty since it was found to be one of the strongest predictors in most of the industries studied by Bloemer, et al. (1999). Also, the findings revealed that tangibles dimension is one of the most important predictor of customer loyalty in ISPs in Jordan. The reason for this result may be that people when recommending an ISP to someone or talking positively about their ISP, think first about the physical thing present in this ISP. Thus, this indicates that factors such modern-looking equipments, employees' appearance, facilities and materials attractiveness are most essential in bringing about customer loyalty. In addition, the findings revealed that reliability is an important predictor of customer loyalty in ISPs in Jordan. This may be due to the fact that each person when thinking about re-subscribing prefers the ISP that can be trusted and can perform the service in a proper way with no or little problems. Thus, this indicate that factors such as keeping promises, interests in solving problems, error-free records, and performing the service right the first time, are most essential in bringing about customer loyalty.

\section{Conclusion}

To gain and sustain competitive advantage in a fast changing industry, it is crucial for a company to understand what customers perceive (Kumar, et al., 2010). Furthermore, the importance of customer loyalty can never be overemphasized because it rellates strongly to the continual survival, as well as the future growth and development of organizations (Cheng, et al, 
2008). The results of multiple regression analysis showed that perceived service quality dimensions have a significant impact on customer loyalty. Furthermore, it was found that empathy is the strongest predictor of customer loyalty. Finally, this study and its findings have a number of contributions and managerial implications.

\subsection{Contributions and Managerial Implications}

Despite the fact that his study was conducted based on existing literature, each of the previous researches was done in a different country with different setting such as different behavior and different culture of customers. Therefore, this study contributes in enabling others to understand the effect of perceived service quality on customer loyalty in ISPs in Jordansince limited efforts were done to study this topic in this particular industry and this particular country. In addition tothat, this study examined the impact of customer perception of service quality and service loyalty from a multidimensional perspective. Thus, using multiple regression analysis, the effect of each of the five elements of the independent variable on the dependent variable was determined.

To the best of our knowledge, similar studies have not been undertaken in the ISP industry in Jordan. Therefore, besides the contribution to theoretical development, the useful findings produced can be utilized by ISPs' managers towards the development andl implementation of practices that will lead to loyal customers. Bloemer, et al. (p.1101, 1999) stated that "companyand industry-level assessment of the service quality-customer loyalty link provides useful information to shareholders on the viability of performance in the future ... The identification of service loyalty as a multi-dimensional construct may help corporate decision makers in an accurate assessment of service loyalty". Thus, this study may enable managers to optimize resource allocation decisions. Indeed, since the way by which resources are allocated to maximize customer loyalty is considered by most managers as a major challenge, an optimal decision of resource allocation requires relevant information about what and how much is to be allocated. Therefore, managers have to be aware of how customer perception of service quality affects customer loyalty and then identify the characteristics of these effects. In addition to that, according to the results of this study, it may be suggested that ISPs' managers deploy their resources first to improve the service quality.

\subsection{Limitations and Recommendations for Future Research}

In view of the fact that the population of this study is very large, the data were not readily available and it was difficult to have access to information that could help in contacting or reaching specific customers because of privacy and security issues. Therefore, this study used convenience sampling, and this might lead one to question the ability to generalize the findings. Thus, future researches are recommended, if possible, to use another probability sampling technique like stratified random sampling to obtain a larger and more diverse sample that could produce more generalizable results. Furthermore, due to the difficulty of access, this research was applied in only one ISP (Umniah) out of ten working ISPs in Jordan. However, this ISP considered being one of the three biggest local ISPs. Taking into consideration the similarity of the ISPs' operations, objectives, and services provided as well as the fact that they operate in the same cultural environment allows for the possibility that the results of this study can be 
generalized to other ISPs in Jordan. However, although the results of this study provide valuable and useful information about perceived service quality and customer loyalty, it is suggested that future researches should be directed towards more ISPs in Jordan in order to obtain more robust results.

Since the results of this study are based on customers' perceptions of service quality only, future researches should investigate the comparison between customers' and service providers' perceptions of service quality. This will help the ISP industry to better understand whether both customers and ISPs have the same perceptions regarding issues relevant to customer loyalty. Moreover, in order to investigate under a more holistic approach customer loyalty, future studies could also examine added concepts that influence loyalty such as trust, emotion, mood, commitment, perceived value, inertia and attractiveness of alternatives. Consequently, the study of these concepts may help in increasing and understanding the explained variance in customer loyalty. Additionally, this study investigated the effect of perceived service quality on customer loyalty in ISPs in Jordan. However, the possibility to generalize the results to other industries and other countries with different characteristics needs to be verified, by executing similar research projects which may add more to the quality-loyally relationship. It is hoped that the findings of this study could motivate further researches in other Arabic countries.

\section{References}

Afsar, B., Rehman, Z.U., Qureshi, J.A., \& Shahjehan, A. (2010). Determinants of customer loyalty in the banking sector: The case of Pakistan. African Journal of Business Management, 4(6), 1040-1047.

Arab Advisors Group (2009). Jordan Telecommunications Market Indicators and Projections. Amman, Jordan.

Bennett, R., \& Rundle-Thiele, S. (2002). A comparison of attitudinal loyalty measurement $\begin{array}{llll}\text { approaches. } & \text { Brand } & \text { Management, } & \text { 9(3), }\end{array}$ http://dx.doi.org/10.1057/palgrave.bm.2540069

Berne, C., Mugica, J.M., \& Yague, M.J. (2001). The effect of variety-seeking on customer retention in services. Journal of Retailing and Consumer Services, 8, 335-345. http://dx.doi.org/10.1016/S0969-6989(01)00002-9

Bloemer, J., Ruyter, K., \& Wetzels, M. (1999). Linking perceived service quality and service loyalty: A multi-dimensional perspective. European Journal of Marketing, 33(11/12), 1082-1106. http://dx.doi.org/10.1108/03090569910292285

Bodet, G. (2008). Customer satisfaction and loyalty in service: Two concepts, four constructs, several relationships. Journal of Retailing and Consumer Services, 15, 156-162. http://dx.doi.org/10.1016/j.jretconser.2007.11.004

Boulding, W., Kalra, A., Staelin, R.,\& Zeithaml, V.A. (1993). A dynamic process model of service quality: From expectations to behavioral intentions. Journal of Marketing Research (JMR), 30(1), 7-27. http://dx.doi.org/10.2307/3172510 


\section{Macrothink}

Journal of Management Research

ISSN 1941-899X

2012, Vol. 4, No. 4

Chadha, S.K., \& Kapoor, D. (2009). Effect of switching cost, service quality and customer satisfaction on customer loyalty of cellular service providers in Indian market. The Icfai University Journal of Marketing Management, 8(1), 23-37.

Chao, P. (2008). Exploring the nature of the relationships between siervice quality and customer loyalty: an attribute-level analysis. The Service Industries Journal, 28(1), 95-116. http://dx.doi.org/10.1080/02642060701725610

Chen, Y.C., Shen, Y.C., \& Liao, S. (2009).An integrated model of customer loyalty: An empirical examination in retailing practice. The Service Industries Journal, 29(3), 267-280. http://dx.doi.org/10.1080/02642060701842886

Cheng, T.C.E, Lai, L.C.F., \& Yeung, A.C.L. (2008). The driving forces of customer loyalty: A study of Internet Service Providers in Hong Kong. International Journal of E-Business Research, 4(4), 26-42. http://dx.doi.org/10.4018/jebr.2008100103

Chiou, J.S. (2004). The antecedents of consumers' loyalty toward internet service providers. Information and Management, 41(6), 685-95. http://dx.doi.org/10.1016/j.im.2003.08.006

Clinton, H.R. (2010). A new nervous system for our planet. Vital Speeches of the Day, 76(3), 108-114.

Clottey,T.A., Collier, A.C, \& Stodnick, M. (2008). Drivers of customer loyalty in a retail store environment. Journal of Service science, 1(1), 35-48.

Copeland, M.T. (1923). Relation of consumers' buying habits to marketing methods. Harvard Business Review, 1(3), 282-289.

Coyles, S. \& Gokey, T.C. (2005). Customer retention is not enough. Journal of Consumer Marketing, 22(2), 101-105. http://dx.doi.org/10.1108/07363760510700041

Cronin jr., J.J., \& Taylor, S.A. (1994). SERVPERF versus SERVQUAL: Reconciling performance-based and perceptions-minus-expectations measurement of service quality. Journal of Marketing, 58, 125-131. http://dx.doi.org/10.2307/1252256

Dick, A.S., \& Basu, K. (1994). Customer loyalty: Toward an integrated conceptual framework. Journal of the Academy of Marketing Science, 22(2), 99-113. http://dx.doi.org/10.1177/0092070394222001

Eze, U.C., Sin, T.K., Ismail, H., \& Siang, P.Y. (2008, December). ISPs' service quality and customer satisfaction in the southern region of Malaysia. 19th Australian Conference on Information Systems, Christchurch, New Zealand.

Fitzgibbon, C., \& White, L. (2005). The role of attitudinal loyalty in the development of customer relationship management strategy within service firms. Journal of Financial Services Marketing, 9(3), 214-230. http://dx.doi.org/10.1057/palgrave.fsm.4770155

Fornell, C. (1992). A national customer satisfaction barometer: The Swedish experience. Journal of Marketing, 56(1), 6-21. http://dx.doi.org/10.2307/1252129 
Geer, S. (2003). Essential Internet: The Essential A-Z. Economist Books: London, UK.

González, M.E.A., Comesaña, L.R., \& Brea, J.A.F. (2007). Assessing tourist behavioral intentions through perceived service quality and customer satisfaction. Journal of Business Research, 60, 153-160. http://dx.doi.org/10.1016/j.jbusres.2006.10.014

Gremler, D., \& Brown, S. (1996). Service loyalty: Its nature, importance and implications. Advancing Service Quality: A Global Perspective, International Service Quality Association, 171-180, New York, NY.

Grewal, D., Levy, M., \& Kumar, V. (2009). Customer experience management in retailing: An organizing framework. Journal of Retailing, 85(1), 1-14. http://dx.doi.org/10.1016/j.jretai.2009.01.001

Gronroos, C. (1984). A Service Quality Model and Its Marketing Implications. European Journal of Marketing, 18(4), 36-44. http://dx.doi.org/10.1108/EUM0000000004784

Harris, L.C., \& Goode, M.M.H. (2004). The four levels of loyalty and the pivotal role of trust: A study of online service dynamics. Journal of Retailing, 80, 139-158. http://dx.doi.org/10.1016/j.jretai.2004.04.002

Hennig-Thurau, T., Gwinner, K.P., \& Gremier, D.D. (2002). Understanding relationship marketing outcomes: An integration of relational benefits and relationship quality. Journal of Service Research, 4(3), 230-47. http://dx.doi.org/10.1177/1094670502004003006

Heskett, J. L., Jones, T.O. et al. (1994),. Putting the Service-Profit Chain to Work. Harvard Business Review, 72(2), 164-170.

Holmund, M., \& Kock, S. (1996). Relationship marketing: the importance of customer-perceived service quality in retail banking. The Service Industry Journal, 16(3), 287-304. http://dx.doi.org/10.1080/02642069600000029

Ibanez, V.A., Hartmann, P., \& Calvo, P.Z. (2006). Antecedents of customer loyalty in residential energy markets: Service quality, satisfaction, trust and switching costs. The Service Industries Journal, 26(6), 633-650.

Ibrahim, H., \& Najjar, F. (2008). Relationship bonding tactics, personality traits, relationship quality and customer loyalty: Behavioral sequence in retail environment. ICFAI Journal of Services Marketing, 6(4), 6-37. http://dx.doi.org/10.1080/02642060600850717

Jacoby, J., \&Kyner, D.B. (1973). Brand loyalty vs. repeat purchasing behavior. Journal of Marketing Research (JMR), 10(1), 1-9. http://dx.doi.org/10.2307/3149402

Janda, S., Trocchia, P. J., \& Gwinner, K. P. (2002). Consumer perceptions of internet retail service quality. International Journal of Service Industry Management, 13(5), 412-431. http://dx.doi.org/10.1108/09564230210447913

Kandampully, J. (1998). Service quality to service loyalty: A relationship which goes beyond customer services. Total Quality Management, 9, 431-443. http://dx.doi.org/10.1080/0954412988370 


\section{Macrothink Institute $^{\text {TM }}$}

Khan, B.M. (2009). Consumers and their brands: Deciphering dimensions of loyalty. International Journal of Business Insights and Transformation, 2(1), 84-92.

Ko, Y.J., \& Pastore, D. (2004). Current issues and conceptualizations of service quality in the recreation sport industry. Sport Marketing Quarterly, 13, 159-167.

Koivisto, M., \& Urbaczewski, A. (2004). The relationship between quality of service perceived and delivered in mobile Internet communications. Information Systems \& e-Business Management, 2(4), 309-323. http://dx.doi.org/10.1007/s10257-004-0045-3

Kumar, S.A., Mani, B.T., Mahalingam, S., \& Vanjikovan, M. (2010). Influence of service quality on attitudinal loyalty in private retail banking: An empirical study. The IUP Journal of Management Research, 9(4), 21-38.

Laroche, M., Ueltschy, L. C., Shuzo, A., \& Cleveland, Y., P. P. (2004). Service quality perceptions and customer satisfaction: Evaluating the role of culture. Journal of International Marketing, 12(3), 58-85. http://dx.doi.org/10.1509/jimk.12.3.58.38100

Lehtinen, U. and Lehtner, J.R. (1982). Service Quality, a Study of Quality Dimensions, Unpublished Working Paper, Service Management Institute, Helsinki.

Lei, M., \& Mac, L. (2005). Service Quality and Customer Loyalty in a Chinese Context: Does Frequency of Usage Matter? ANZMAC 2005 Conference: Service Marketing, Fremantle, Western Australia.

Lewis, R.C., \& Booms, B.H. (1983). The Marketing Aspects of Service Quality. In: Berry, L., G. Shostack and G.D. Upah, (Eds.), Emerging Perspectives on Service Marketing. AMA, New York.

Lin, H.H., \& Wang, Y.S. (2006). An examination of the determinants of customer loyalty in mobile commerce contexts. Information and Management, 43, 271-282. http://dx.doi.org/10.1016/j.im.2005.08.001

Liang, C.J., \& Wang, W.H. (2004). Attribute, benefits, customer satisfaction and behavioral loyalty: An integrative research of financial services industry in Taiwan. Journal of Services Research, 4(1), 57-91.

Lobo, A., Maritz, A., \& Mehta, S. (2007). Enhancing Singapore travel agencies' customer loyalty: An empirical investigation of customers' behavioral intentions and zones of tolerance. International Journal of Tourism Research, 9, 485-495. http://dx.doi.org/10.1002/jtr.619

Lorenzo, L., Foley, S., Dipp, J., Lane, S., \& Minh, L. (2010). How service quality affects customer loyalty. Allied Academies International Conference: Proceedings of Academy of Information and Management Sciences (AIMS), 14(1), 49-53.

Martin, W.C., Ponder, N., \& Lueg, J.E. (2009). Price fairness perceptions and customer loyalty In a retail context. Journal of Business Research, 62(6), 588-593. http://dx.doi.org/10.1016/j.jbusres.2008.05.017 
Ministry of Information and Communication Technology. (2011). Available from: http://www.moict.gov.jo/ [Accessed June, 2012].

Monroe, K. B., \& Guiltinan, J.P. (1975). A Path Analytic Exploration of Retail Patronage Influences. Journal of Consumer Research, 2(2), 19-28. http://dx.doi.org/10.1086/208612

Oliver, R.L. (1980). A cognitive model of the antecedents and consequences of satisfaction decisions. Journal of Marketing Research (JMR), 17(4), 460-469. http://dx.doi.org/10.2307/3150499

Oliver, R. L. (1997). Satisfaction: A Behavioral Perspective on the Consumer. New York, NY: McGraw-Hill.

Oliver, R.L. (1999). Whence consumer loyalty? Journal of Marketing, 63(4), 33-44. http://dx.doi.org/10.2307/1252099

Pan, Y., \& Xie, F.T. (2008), Antecedents and consequences of customer loyalty: An empirical synthesis and reexamination. Latin American Advances in Consumer Research, 2, 173-173.

Parasuraman, A., Zeithaml, V.A., \& Berry, L. L. (1985). A conceptual model of service quality and its implications for future research. Journal of Marketing, 49(4), 41-50. http://dx.doi.org/10.2307/1251430

Parasuraman, A., Zeithaml, V.A., \& Berry, L. L. (1988). SERVQUAL: A multiple-item scale for measuring consumer perceptions of service quality. Journal of Retailing, 24(1), 12-40.

Parasuraman, A., Zeithaml, V. A., \& Berry, L. L. (1990). Moving Forward in Service Quality Research: Measuring Different Customer Expectation Levels, Comparing Alternative Scales, and Examining the Performance-Behavioral Intentions Link. MSI Report No. 94-114.

Parasuraman, A., Zeithaml, V.A., \& Berry, L. L. (1991). Refinement and reassessment of the SERVQUAL scale. Journal of Retailing, 67(1), 420-450.

Parasuraman, A., Zeithaml, V.A., \& Berry, L. L. (1994). Alternative scales for measuring service quality: A comparative assessment based on psychometric and diagnostic criteria. Journal of Retailing, 70(1), 201-230. http://dx.doi.org/10.1016/0022-4359(94)90033-7

Rahman, Z. (2006). Superior service quality in Indian Cellular Telecommunication Industry: A source of sustainable competitive advantage in and emerging economy. Service Marketing Quarterly, 27(4) 115-139. http://dx.doi.org/10.1300/J396v27n04_07

Ranaweera, C., \& Neely, A. (2003). Some moderating effects on the service quality-customer retention link. International Journal of Operations and Production Management, 23(2), 230-248. http://dx.doi.org/10.1108/01443570310458474

Ravichandran, K., Bhargavi, K., \& Kumar, S.A. (2010). Influence of service quality on banking customers' Behavioral intentions. International Journal of Economics and Finance, 2(4), 18-28. 


\section{Macrothink Institute ${ }^{\mathrm{TM}}$}

Ribbink, D., Riel, A.C.R., Liljander, V., \& Streukens, S. (2004). Comfort your online customer: Quality, trust and loyalty on the internet. Managing Service Quality, 14(6), 446-456. http://dx.doi.org/10.1108/09604520410569784

Rowley, J. (2004). Loyalty and rewards schemes: How much is your loyalty worth?. The Marketing Review, 4, 121-138. http://dx.doi.org/10.1362/1469347041569795

Rundle-Thiele, S. (2005). Elaborating customer loyalty: Exploring loyalty to wine retailers. Journal of Retailing and Consumer Services, 12, 333-344. http://dx.doi.org/10.1016/j.jretconser.2004.11.002

Sanchez-Franco, M.J., Ramos, A.F.V., \& Velicia, F.A.M. (2009). The moderating effect of gender on relationship quality and loyalty towards Internet service providers. Information and Management, 46(3), 196-202. http://dx.doi.org/10.1016/j.im.2009.02.001

Santouridis, I. \& Trivellas, P. (2010). Investigating the impact of service quality and customer Satisfaction on customer loyalty in mobile telephony in Greece. The TQM Journal, 22(3), 330-343. http://dx.doi.org/10.1108/17542731011035550

Saunders, M., Lewis, P., \& Thornhill, A. (2007). Research Methods for Business Students (4th ed.). Edinburgh Gate, Harlow: Financial Times Prentice Hall.

Seth, A., Momaya, K., \& Gupta, H.M. (2008). Managing the Customer Perceived Service Quality for Cellular Mobile Telephony: An Empirical Investigation. Vikalpa: The Journal for Decision Makers, 33(1), 19-34.

Sekaran, U. (2003). Research Methods for Business: A Skill Building Approach (4th ed.). John Willey and Sons, Ltd.

Shankar, V., Smith, A.K., \& Rangaswamy, A. (2003), Customer satisfaction and loyalty in Online and offline environments. International Journal of Research in Marketing, 20(2), 153-175. http://dx.doi.org/10.1016/S0167-8116(03)00016-8

Shonk, D.J., \& Chelladurai, P. (2008). Service quality, satisfaction, and intent to return in event sport tourism. Journal of Sport Management, 22, 587-602.

Umniah Telecommunication Company (2011). Umniah Profile, Amman, Jordan. Available from: http://umniah.com/ [Accessed July 2012].

Vanniarajan, T., \& Gurunathan, P. (2009). Service quality and customer loyalty in cellular service market: An application of 'Sem.'. Journal of marketing and Communication, 5(2), 45-54.

Webster, F.E. (1992). The changing role of marketing in the corporation. Journal of Marketing, 56, 1-17. http://dx.doi.org/10.2307/1251983

Wicks, A.M., \& Roethlein, C.J. (2009). A satisfaction-Based definition of quality. Journal of Business and Economic Studies, 15(1), 82-97. 


\section{Macrothink}

Journal of Management Research

ISSN 1941-899X

2012, Vol. 4, No. 4

White, C.J. (2006). Towards an understanding of the relationship between mood, emotions, service quality and customer loyalty intentions. The Service Industries Journal, 26(8), 837-847. http://dx.doi.org/10.1080/02642060601011624

Xu, Y., Goedegebuure, R., \& Heijden, B. (2006). Customer perception, customer satisfaction, and customer loyalty within Chinese securities business: Towards a mediation model for predicting customer behavior. Journal of Relationship Marketing, 4, 79-104. http://dx.doi.org/10.1300/J366v05n04_06

Yieh, K., Chiao, Y.C., \& Chiu, Y.K. (2007). Understanding the antecedents to customer loyalty by applying structural equation modeling. Total Quality Management, 18(3), 267-284. http://dx.doi.org/10.1080/14783360601152400

Yim, C.K., Tse, D.K., \& Chan, K.W. (2008). Strengthening customer loyalty through intimacy and passion: Roles of customer-firm affection and customer-staff relationships in services. Journal of Marketing Research (JMR), 45(6), 741-756. http://dx.doi.org/10.1509/jmkr.45.6.741

Yu, C.M. J., Wu, L.Y., Chiao, Y.C., \& Tai, H.S. (2005). Perceived quality, customer satisfaction, and customer loyalty: The case of Lexus in Taiwan. Total Quality Management and Business Excellence, 16(6), 707-719. http://dx.doi.org/10.1080/14783360500077393

Zeithaml, V. A. (1987). Defining and Relating Price, Perceived Quality, and Perceived Value, Report No. 87-101, Cambridge, MA: Marketing Science Institute.

Zeithaml, V.A., Berry, L.L., \& Parasuraman, A. (1996). The behavioral consequences of service quality. Journal of Marketing, 60, 31-46. http://dx.doi.org/10.2307/1251929 